\title{
Aras kerusakan ekonomi (AKE) larva Ostrinia furnacalis (Lepidoptera: Crambidae) pada tiga fase pertumbuhan tanaman jagung
}

\author{
Economic injury level (EIL) of Ostrinia furnacalis (Lepidoptera: \\ Crambidae) larvae on three growth stages of corn \\ Subiadi $^{1 *}$, Y. Andi Trisyono ${ }^{2}$, Edhi Martono ${ }^{2}$ \\ ${ }^{1}$ Balai Pengkajian Teknologi Pertanian Papua Barat \\ Jalan Base Camp - Arfai Gunung Kompleks Perkantoran Pemda \\ Papua Barat, Manokwari 98315 \\ ${ }^{2}$ Jurusan Hama dan Penyakit Tumbuhan, Fakultas Pertanian,Universitas Gadjah Mada \\ Jalan Flora No.1 Bulaksumur, Yogyakarta 55281
}

(diterima Juli 2013, disetujui Januari 2014)

\begin{abstract}
ABSTRAK
Penggerek batang jagung Asia, Ostrinia furnacalis (Guenée) merupakan hama penting tanaman jagung dan telah tersebar luas di wilayah Asia-Pasifik termasuk Indonesia sehingga perlu dikendalikan dengan memperhatikan analisis biaya dan manfaat pengendalian. Penelitian ini bertujuan untuk mengetahui hubungan kepadatan populasi larva $O$. furnacalis terhadap tingkat kehilangan hasil pada tiga fase pertumbuhan tanaman jagung, dan untuk menghitung nilai aras luka ekonomi (ALE) larva O. furnacalis pada tiga fase pertumbuhan tanaman jagung (V10, R1, dan R2). Percobaan ditata berdasarkan rancangan petak terpisah dengan rancangan lingkungan rancangan acak kelompok yang diulang tiga kali. Selisih bobot biji gram per tanaman antara tanaman yang tidak diinfestasi larva (kontrol) dan infestasi enam larva per tanaman untuk fase V10, R1, dan R2, masing-masing adalah 59,81, 58,76, dan 49,20 g/tanaman. Model regresi linier menunjukkan bahwa setiap pertambahan satu larva per tanaman pada fase V10, R1, dan R2 akan menurunkan hasil masing-masing 4,94\%, $4,56 \%$, dan 3,76\%. Nilai ALE dikalkulasi dengan asumsi pengendalian dengan pestisida akan menurunkan populasi larva O. furnacalis sebesar $67 \%$. Nilai ALE terendah terdapat pada fase V10 sebesar 0,31 larva per tanaman ketika biaya pengendalian Rp.125.000 per ha dan nilai tanaman Rp.12.000.000 per ha. Nilai ALE tertinggi terdapat pada fase R2 sebesar 1,24 larva per tanaman ketika biaya pengendalian Rp.250.000 per ha dan nilai tanaman Rp.8.000.000 per ha.
\end{abstract}

Kata kunci: jagung, kehilangan hasil, Ostrinia furnacalis

\begin{abstract}
The Asian corn borer, Ostrinia furnacalis (Guenée) is an important economic pest of corn and is widely distributed in the Asia-Pacific region, including Indonesia. The objective of this research is to investigate the effect of infestation levels of $O$. furnacalis larvae per plant on corn grain yield reductions, and to determine economic injury levels (EIL) of $O$. furnacalis larvae at three growth stages (V10, R1, and R2) of corn. The experiment was designed in a split-plot randomized complete
\end{abstract}

\footnotetext{
*Penulis korespondensi: Subiadi. Balai Pengkajian Teknologi Pertanian Papua Barat,

Jalan Base Camp - Arfai Gunung, Kompleks Perkantoran Pemda, Provinsi Papua Barat, Manokwari 98315

Tel: 081343673122,Email: subiadisaide@gmail.com, bptp_papuabarat@yahoo.com.
} 


\begin{abstract}
block with blocks replicated three times. Differences in grain weight between the uninfested and highest infestation levels (six larvae per plant) V10, R1, and R2 were 59.81; 58.76; and $49.20 \mathrm{~g}$ / plant, respectively. For each additional infestation by one larvae per plant at V10, R1, dan R2, there is reduction in grain weight of $4.94 \%, 4.56 \%$ and $3.76 \%$ respectively. The calculation of EILs was based on the proportion of yield loss per larvae per plant on three corn growth stages with the assumption that pesticide control reduced $67 \%$ of $O$. furnacalis population. The lowest EIL was 0.31 larvae per plant at V10 when the cost of control reaching Rp.125,000 per ha and crop value of Rp.12,000,000 per ha. The highest EIL of 1.24 larvae per plant was found at R2 with the cost of control of Rp.250,000 per ha and crop value of Rp.8,000,000 per ha.
\end{abstract}

Key words: corn, Ostrinia furnacalis, yield loss

\section{PENDAHULUAN}

Salah satu hama yang memiliki arti penting terhadap budi daya tanaman jagung adalah genus Ostrinia (Crambidae: Pyraustinae), yaitu penggerek batang jagung Eropa $O$. nubilalis (Hubner) dan penggerek batang jagung Asia O. furnacalis (Guenee) (Ohno et al. 2003). O. furnacalis merupakan hama penting pada jagung di Filipina, Kamboja, Vietnam, Cina, Indonesia, Thailand, Malaysia, dan Papua New Guinea (Granados 2000). Di Indonesia serangga ini menyebar luas di Papua, Nusa Tenggara, Sulawesi, dan Sumatera (Waterhouse 1993).

O. furnacalis merupakan hama minor dan sporadis pada tanaman jagung, tetapi bila terjadi serangan bobot, kehilangan hasil bisa mencapai 20-80\% (Guo \& Li 2009). Saat ini O. furnacalis menjadi hama penting dimanapun jagung dibudidayakan (Capinera 2008).

Kehilangan hasil dapat berbeda pada berbagai tempat bergantung pada kepadatan populasi larva dan umur tanaman saat diserang (Nonci 2004). Larva O. furnacalis mulai menyerang jagung pada minggu ketiga setelah penanaman dengan memakan daun dan mulai menggerek batang dari minggu kelima setelah penanaman sampai panen (Douangboupha et al. 2006). Kehilangan hasil mencapai $28 \%$ terjadi pada batang yang ditemukan satu lubang gerekan, dan $48 \%$ pada batang yang ditemukan empat lubang gerekan (Litsinger et al. 2007).

Pengendalian hama sering difokuskan pada tindakan pencegahan dan tidak didasarkan pada analisis manfaat sehingga terkadang biaya yang dikeluarkan untuk pengendalian hanya menambah ongkos produksi karena pengendalian dilakukan sebelum ada hama, atau hama sudah merusak baru dikendalikan. Karena itu, perlu penentuan tingkat kepadatan populasi hama yang menjadi dasar untuk pengambilan keputusan pengendalian hama yang disebut dengan nilai aras kerusakan ekonomi (AKE). Nilai AKE adalah tingkat kepadatan populasi hama yang merupakan titik impas antara biaya pengendalian dan hasil yang terselamatkan bila dilakukan pengendalian. Penelitian bertujuan untuk mengetahui hubungan kepadatan populasi larva $O$. furnacalis terhadap tingkat kehilangan hasil pada tiga fase pertumbuFhan tanaman jagung, dan untuk menghitung nilai AKE larva $O$. furnacalis pada tiga fase pertumbuhan tanaman jagung (V10, R1, dan R2).

\section{BAHAN DAN METODE}

\section{Perbanyakan $O$. furnacalis di laboratorium}

Pembiakan massal $O$. furnacalis dilaksanakan di Laboratorium Toksikologi Fakultas Pertanian, Universitas Gadjah Mada (UGM) menggunakan pakan buatan mengikuti metode yang telah digunakan di laboratorium sejak tahun 2009. Larva yang digunakan berasal dari generasi $O$. furnacalis yang sudah dipelihara di laboratorium sejak tahun 2009.

\section{Percobaan lapangan}

Percobaan lapang dilaksanakan di Kebun Pendidikan, Penelitian, dan Pengembangan Pertanian (KP4) UGM, Yogyakarta dari Oktober 2011 sampai Februari 2012. Percobaan ditata berdasarkan rancangan petak terpisah (RPT) dengan rancangan lingkungan rancangan acak kelompok (RAK) yang diulang tiga kali. Setiap ulangan terdiri atas petak utama yang mewakili dua fase pertumbuhan tanaman jagung (V10: 
10 daun terbuka sempurna, dan R1: keluarnya rambut tongkol). Petak utama terdiri atas anak petak mewakili enam tingkat infestasi larva O. furnacalis per tanaman $(0,1,2,3,4$, dan 5 individu per tanaman). Variasi tingkat infestasi larva tersebut digunakan karena lima lubang gerekan per tanaman paling banyak ditemukan pada tanaman jagung bila terserang $O$. furnacalis (Abdullah \& Rauf 2011).

Anak petak (ukuran 3,2 $\mathrm{m} \times 2,6 \mathrm{~m}$ ) ditanami jagung hibrida varietas Pioneer 21 dengan jarak tanam $80 \mathrm{~cm} \times 20 \mathrm{~cm}$ sehingga diperoleh lima baris tanaman dan tiap baris terdapat 14 rumpun tanaman dengan satu tanaman per rumpun (70 tanaman/petak). Jarak antar kelompok 2 meter, jarak antar petak utama $2 \mathrm{~m}$, dan jarak antar anak petak $1,5 \mathrm{~m}$.

Penggunaan insektisida berbahan aktif Deltametrin dilakukan pada saat tanaman berumur 8 hari setelah tanam (HST) untuk mengendalikan serangan kumbang Chrysomelidae dan lalat bibit. Selanjutnya tanaman tidak disemprot lagi dengan insektisida hingga panen. Hama lain yang ditemukan, yaitu penggerek tongkol jagung dengan tingkat populasi yang rendah, dan dikendalikan secara mekanik dengan mengumpulkan dan mematikan larva yang ditemukan.

Infestasi larva $O$. furnacalis secara buatan. Infestasi larva pada setiap perlakuan dilakukan pada 10 tanaman yang dipilih pada tiga baris tanaman di bagian tengah setiap anak petak. Semua tingkat infestasi digunakan larva instar III karena larva instar III yang mulai menggerek batang (Jordan 2008; Tiwari et al. 2009).

Larva diinfestasi dengan menggunakan selang plastik yang berukuran diameter bagian dalam $1,1 \mathrm{~cm}$ yang dipotong dengan ukuran panjang $3,5 \mathrm{~cm}$ sehingga bentuknya menyerupai tabung. Sisi kiri dan kanan tabung dibelah dengan kemiringan $\pm 15^{\circ}$ sedalam $\pm 1 \mathrm{~cm}$. Pada masingmasing sisi yang terbelah tersebut dipasang satu buah karet gelang kemudian dibalut dengan solasi (vinyl electrical tape) untuk menutup celah bekas irisan. Salah satu ujung dari selang plastik dimodifikasi menyerupai lengkungan alami batang jagung agar tidak ada celah bagi larva untuk melarikan diri. Ujung tabung lainnya ditutup dengan menggunakan tutup botol diameter $1,1 \mathrm{~cm}$. Metode ini merupakan modifikasi dari metode wire-nut oleh Tiwari et al. (2009).

Pada fase V10, semua larva ditempatkan pada ruas batang jagung yang daunnya sudah terbuka sempurna dengan satu larva per ruas (masingmasing tabung diisi dengan satu larva). Pada fase $\mathrm{R} 1$, setengah dari jumlah larva ditempatkan pada ruas yang ada di atas tongkol dan setengah sisa ditempatkan pada ruas yang ada di bawah tongkol (untuk infestasi dua dan empat larva). Pada tingkat infestasi tiga dan lima larva per tanaman, larva sisa ditempatkan di bawah tongkol (Jordan 2008). Pada tingkat infestasi satu larva per tanaman, larva ditempatkan di bawah tongkol. Untuk memudahkan penetrasi larva, setiap ruas batang jagung yang dipasangi tabung dibor sedalam $4 \mathrm{~mm}$ dengan menggunakan mata bor kayu diameter $5 \mathrm{~mm}$.

Larva yang diinfestasi buatan pada fase V10, sekitar $90 \%$ berhasil menggerek batang 24 jam setelah infestasi dan tabung infestasi dilepas dari batang jagung setelah larva berhasil menggerek batang. Sekitar $10 \%$ larva mati dalam tabung karena terendam air hujan sebelum berhasil menggerek batang. Pada fase R1, hanya sekitar 6\% larva yang mati dalam tabung dengan penyebab yang sama pada fase V10. Larva yang mati diganti 24 jam setelah infestasi awal, dan larva 100\% berhasil menggerek batang pada hari ketiga dari infestasi awal.

Infestasi larva $O$. furnacalis secara alami. Pada saat tanaman berumur 67 HST (fase R2: rambut tongkol telah kering), terjadi infestasi alami larva $O$. furnacalis pada tanaman sebesar $88,3 \%$ termasuk tanaman yang telah diinfestasi secara buatan. Infestasi alami larva pada bunga jantan, bunga betina, dan tongkol dikendalikan secara mekanik. Sebanyak 162 tanaman diambil secara acak sebagai sampel untuk pengamatan tanaman yang terinfestasi secara alami pada fase R2, diluar tanaman yang telah diinfestasi larva secara buatan. Tanaman contoh untuk kontrol diambil secara sengaja dengan mengambil tanaman yang bebas serangan larva sebanyak 60 tanaman (20 tanaman per blok). Rata-rata hasil biji dari tanaman kontrol digunakan sebagai pembanding rata-rata hasil untuk semua fase tanaman. 


\section{Pengukuran parameter penelitian}

Jumlah lubang gerekan. Jumlah lubang gerekan per tanaman pada setiap perlakuan diamati dan dihitung pada saat panen.

Hasil biji pipilan kering (PK). Tongkol jagung dipisahkan dari kelobotnya dan dikeringkan selama satu minggu di rumah kaca kemudian dipipil. Hasil biji pipilan dimasukkan ke dalam kantong plastik masing-masing satu tongkol per plastik. Biji per tongkol kemudian ditimbang dengan timbangan

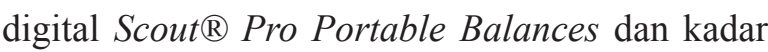
air diukur dengan Dole ${ }^{\circledR}-$ Radson Moisture Tester Model 400B. Hasil biji pipilan kering dihitung pada kadar air yang sama $(\mathrm{ka}=14 \%)$ dengan persamaan:

$$
\mathrm{Bb}(\mathrm{Ka} 14 \%)=\frac{\mathrm{Bt} \times(100-\mathrm{Kat})}{(100-14)}
$$

dengan $\mathrm{Bb}$ : bobot biji; Bt: bobot biji terukur; dan Kat: kadar air terukur.

Proporsi kehilangan hasil per larva per tanaman. Proporsi kehilangan hasil dihitung berdasarkan persamaan Walker (1983), sebagai berikut:

$$
r=\frac{(Y p-Y r)}{Y p}
$$

dengan $r$ : proporsi kehilangan hasil; $Y p$ : hasil panen pada kontrol; dan $Y r$ : hasil panen yang diperoleh pada perlakuan.

Kehilangan hasil diasumsikan sebagai model linier antara persentase kehilangan hasil dan jumlah larva per tanaman. Kehilangan hasil yang diakibatkan oleh satu individu larva per tanaman ditentukan dengan metode regresi linier $\mathrm{y}=\mathrm{a}+\mathrm{bx}$, hubungan antara kepadatan populasi hama dan proporsi kehilangan hasil (Jordan 2008), dengan y: proporsi kehilangan hasil, a: intercept; b: proporsi kehilangan hasil per larva per tanaman; dan $\mathrm{x}$ : jumlah larva per tanaman.

Aras kerusakan ekonomi (AKE) larva $\boldsymbol{O}$. furnacalis. AKE atau economic injury level (EIL) dihitung dengan metode yang dikembangkan oleh Bode \& Calvin (1990) dengan persamaan:

$$
\mathrm{EIL}=\frac{\mathrm{TC}}{\mathrm{CV} \times \mathrm{PL} \times \mathrm{PC}} \text { dan } \mathrm{CV}=\mathrm{MV} \times \mathrm{EY},
$$

dengan TC: total biaya untuk sekali pengendalian termasuk harga pestisida dan upah tenaga penyemprot (Rp/ha); PL: proporsi kehilangan hasil per larva per tanaman (sama dengan nilai koefisien "b" pada analisis regresi); CV: nilai hasil tanaman; MV: harga hasil tanaman di pasaran (Rp/ $\mathrm{kg}$ ); EY: prediksi hasil bila tidak terjadi serangan hama yang diteliti atau kontrol ( $\mathrm{kg} / \mathrm{ha})$; dan PC: proporsi penurunan populasi hama karena tindakan pengendalian.

Analisis ragam. Data hasil panen pada perlakuan fase tanaman dan tingkat infestasi larva dianalisis dengan menggunakan ANOVA dua arah untuk rancangan petak terpisah dengan program SAS (SAS Institute 2001). Uji Post Hoc dilakukan dengan duncan's multiple range test (DMRT) pada tingkat ketelitian $95 \%$ jika terdapat pengaruh beda nyata pada perlakuan yang diuji. ANOVA regresi linier hubungan antara jumlah larva per tanaman dan proporsi kehilangan hasil dibuat untuk setiap fase pertumbuhan tanaman dengan program SAS.

\section{HASIL}

\section{Hubungan antara rata-rata hasil biji dan jumlah larva $O$. furnacalis per tanaman}

Lubang gerekan pada setiap tanaman sampel dihitung secara keseluruhan, baik lubang gerekan karena infestasi buatan maupun lubang gerekan tambahan karena infestasi alami. Jumlah lubang gerekan akhirnya ada yang mencapai enam lubang per tanaman. Diasumsikan bahwa jumlah lubang gerekan sama dengan jumlah larva (satu larva hanya membuat satu lubang gerekan). Tanaman sampel yang terserang penyakit tidak dimasukkan dalam pengumpulan data.

Rata-rata hasil biji (g/tanaman) yang diassosiasikan dengan standar deviasi (SD) untuk tiga fase pertumbuhan tanaman jagung menunjukkan bahwa rata-rata hasil biji semakin rendah dengan bertambahnya jumlah infestasi larva per tanaman (Tabel 1).

Hasil analisis SAS general linier model (GLM) untuk rancangan petak terbagi (RPT) menunjukkan bahwa interaksi tingkat infestasi larva dan fase pertumbuhan tanaman jagung menghasilkan pengaruh yang tidak signifikan terhadap hasil biji 
$\left(\mathrm{F}_{12,62}=1,16 ; \mathrm{P}=0,35\right)$. Hasil ini menunjukkan bahwa tingkat infestasi larva dengan jumlah yang sama per tanaman pada tiga fase pertumbuhan tanaman jagung menyebabkan kehilangan hasil yang tidak berbeda nyata. Misalnya infestasi satu larva per tanaman pada fase V10 menyebabkan kehilangan hasil yang tidak berbeda nyata dengan infestasi satu larva per tanaman pada fase R1 dan R2.

Faktor fase tanaman menghasilkan pengaruh yang signifikan terhadap hasil biji $\left(\mathrm{F}_{2,62}=4,07\right.$; $\mathrm{P}=0,0255)$. Hasil ini menunjukkan bahwa fase tanaman yang berbeda memiliki respon yang berbeda terhadap berbagai tingkat infestasi larva per tanaman. Faktor jumlah larva per tanaman menghasilkan pengaruh yang signifikan terhadap hasil biji $\left(\mathrm{F}_{6,62}=45,31 ; \mathrm{P}=0,0001\right)$. Rata-rata hasil biji semakin rendah dengan tingkat infestasi larva yang semakin tinggi.

\section{Regresi linier hubungan antara proporsi kehilangan hasil dan jumlah larva $O$. furnacalis per tanaman}

Proporsi kehilangan hasil per larva per tanaman lebih tinggi pada fase V10 dan nilainya menurun dengan bertambahnya umur tanaman (fase R1 dan $\mathrm{R} 2$ ), dan proporsi kehilangan hasil pada ketiga fase pertumbuhan tanaman jagung meningkat secara linier dengan bertambahnya jumlah infestasi larva per tanaman (Tabel 2).

Hasil analisis regresi linier hubungan antara proporsi kehilangan hasil dan jumlah larva per tanaman menghasilkan pengaruh yang signifikan untuk semua fase tanaman $\left(\mathrm{F}_{1,20}=126,34 ; \mathrm{P}=\right.$ 0,$0001 ; R^{2}=0,87$ untuk fase V10; $F_{1,20}=77,82$; $\mathrm{P}=0,0001 ; \mathrm{R}^{2}=0,80$ untuk fase $\mathrm{R} 1$; dan $\mathrm{F}_{1,20}=$ 47,$60 ; P=0,0001 ; R^{2}=0,71$ untuk fase $\left.R 2\right)$. Hal ini menunjukkan bahwa model linier hubungan antara jumlah larva per tanaman dan proporsi kehilangan hasil terpenuhi. Berdasarkan prediksi analisis regresi linier, setiap pertambahan infestasi satu ekor larva per tanaman menyebabkan bertambahnya proporsi kehilangan hasil sebesar 0,0494 pada fase V10; 0,0456 pada fase R1; dan 0,0376 pada fase $\mathrm{R} 2$.

\section{Aras kerusakan ekonomi (AKE) larva $O$. furnacalis}

Komponen-komponen dalam AKE, seperti biaya pengendalian (TC) dan nilai tanaman (CV) bisa berbeda berdasarkan tempat dan waktu sehingga nilai AKE pada studi ini dihitung pada berbagai variasi TC dan CV. Semakin banyak variasi TC dan CV yang disajikan pada tabel AKE,

Tabel 1. Rata-rata $( \pm \mathrm{SD})$ hasil biji (g/tanaman) pada berbagai tingkat infestasi larva Ostrinia furnacalis untuk tiga fase pertumbuhan tanaman jagung hibrida Pioneer 21 (V10, R1, dan R2)

\begin{tabular}{ccccccc}
\hline & \multicolumn{7}{c}{ Rata-rata $( \pm$ SD) hasil biji (g/tanaman) } \\
\cline { 2 - 7 } $\begin{array}{c}\text { Jumlah larva } \\
\text { per tanaman }\end{array}$ & $\begin{array}{l}\text { Jumlah } \\
\text { tanaman } \\
\text { sampel }\end{array}$ & Fase V10 & $\begin{array}{l}\text { Jumlah } \\
\text { tanaman } \\
\text { sampel }\end{array}$ & Fase R1 & $\begin{array}{l}\text { Jumlah } \\
\text { tanaman } \\
\text { sampel }\end{array}$ & Fase R2 \\
\hline 0 & 60 & $208,33 \pm 1,13 \mathrm{a}$ & 60 & $208,33 \pm 1,13 \mathrm{a}$ & 60 & $208,33 \pm 1,13 \mathrm{a}$ \\
1 & 3 & $206,76 \pm 1,70 \mathrm{a}$ & 1 & $189,16 \pm 0,00 \mathrm{~b}$ & 29 & $192,97 \pm 3,02 \mathrm{~b}$ \\
2 & 15 & $201,62 \pm 13,50 \mathrm{~b}$ & 7 & $187,98 \pm 18,23 \mathrm{~b}$ & 29 & $188,72 \pm 3,48 \mathrm{~b}$ \\
3 & 18 & $175,53 \pm 7,85 \mathrm{c}$ & 18 & $174,59 \pm 14,38 \mathrm{c}$ & 34 & $179,36 \pm 1,49 \mathrm{c}$ \\
4 & 31 & $173,48 \pm 2,09 \mathrm{c}$ & 26 & $160,71 \pm 11,77 \mathrm{~d}$ & 39 & $179,49 \pm 5,53 \mathrm{c}$ \\
5 & 31 & $165,65 \pm 9,51 \mathrm{~d}$ & 30 & $157,51 \pm 5,64 \mathrm{~d}$ & 27 & $161,69 \pm 8,84 \mathrm{~d}$ \\
6 & 18 & $148,52 \pm 4,83 \mathrm{e}$ & 16 & $149,57 \pm 0,56 \mathrm{e}$ & 4 & $159,13 \pm 26,95 \mathrm{~d}$ \\
\hline Rata-rata $( \pm \mathrm{SE})^{2}$ & & $182,84 \pm 6,28 \mathrm{a}$ & & $175,41 \pm 8,97 \mathrm{~b}$ & $1,38 \pm 10,97 \mathrm{a}$ \\
\hline
\end{tabular}

${ }^{1}$ Nilai pada kolom yang diikuti dengan huruf yang sama tidak berbeda nyata (Duncan, $\mathrm{P}>0,05$ ).

${ }^{2}$ Nilai pada baris yang diikuti dengan huruf yang sama tidak berbeda nyata (Duncan, $\mathrm{P}>0,05$ ).

Tabel 2. Formula regresi linier hubungan antara proporsi kehilangan hasil dengan jumlah larva Ostrinia furnacalis pada tiga fase pertumbuhan jagung hibrida Pioneer 21 (V10, R1, dan R2)

\begin{tabular}{|c|c|c|c|c|c|}
\hline \multirow{2}{*}{$\begin{array}{l}\text { Fase } \\
\text { tanaman }\end{array}$} & \multirow{2}{*}{ Regresi linier } & \multicolumn{2}{|c|}{$\mathrm{SE}$} & \multirow{2}{*}{$\mathrm{R}^{2}$} & \multirow{2}{*}{$\operatorname{Pr}>F$} \\
\hline & & Slope & Intercept & & \\
\hline$\overline{\mathrm{V} 10}$ & $Y=0,0494 X-0,0255$ & 0,0044 & 0,0159 & 0,8693 & 0,0001 \\
\hline $\mathrm{R} 1$ & $Y=0,0456 X+0,0217$ & 0,0052 & 0,0186 & 0,8038 & 0,0001 \\
\hline $\mathrm{R} 2$ & $Y=0,0376 X+0,0166$ & 0,0054 & 0,0196 & 0,7147 & 0,0001 \\
\hline
\end{tabular}


semakin baik untuk mengakomodasi kemungkinan perbedaan yang lebih besar pada komponenkomponen tersebut.

Proporsi pengendalian (PC) didasarkan pada penggunaan pestisida karena sampai saat ini cara pengendalian yang masih menjadi andalan petani adalah pestisida. Diasumsikan bahwa penggunaan pestisida cair hanya mampu mengendalikan $67 \%$ populasi $O$. furnacalis di lapangan $(\mathrm{PC}=0,67)$. Nilai PC bisa disesuaikan dengan efikasi pestisida yang digunakan pada daerah setempat berdasarkan hasil penelitian atau pengalaman petani di lapangan.

AKE merupakan tingkat kepadatan populasi hama yang merupakan titik impas antara biaya pengendalian dan hasil yang terselamatkan bila dilakukan pengendalian. Pada studi ini, ketika biaya pengendalian dan nilai tanaman berada pada level terendah maka nilai AKE pada fase V10 adalah $125.000 /(8.000 .000 \times 0,0494 \times 0,67)$ $=0,47$ larva per tanaman atau 47 larva per 100 tanaman yang diamati; sebaliknya ketika biaya pengendalian dan nilai tanaman berada pada level tertinggi maka nilai AKE pada fase V10 adalah $250.000 /(12.000 .000 \times 0,0494 \times 0,67)=0,63$ larva per tanaman atau 63 larva per 100 tanaman. Ketika biaya pengendalian berada pada level tinggi dan nilai tanaman pada level rendah, nilai AKE untuk fase V10 adalah 250.000 / (8.000.000 $\times 0,0494 \times 0,67)=0,94$ larva per tanaman atau 94 larva per 100 tanaman; sebaliknya ketika biaya pengendalian berada pada level rendah dan nilai tanaman pada level tinggi maka nilai AKE untuk fase V10 adalah $125.000 /(12.000 .000 \times 0,0494$ $\times 0,67)=0,31$ larva per tanaman atau 31 larva per 100 tanaman. Metode yang sama digunakan untuk

Tabel 3. Nilai aras kerusakan ekonomi (AKE) Ostrinia furnacalis (larva per tanaman) untuk beberapa variasi total biaya pengendalian dan prediksi nilai tanaman untuk tiga fase pertumbuhan tanaman jagung

\begin{tabular}{|c|c|c|c|c|c|c|}
\hline \multirow{2}{*}{$\begin{array}{l}\text { Nilai tanaman } \\
(\mathrm{CV})(\mathrm{Rp} / \mathrm{ha})\end{array}$} & \multicolumn{6}{|c|}{ Total biaya pengendalian (TC) (Rp/ha) } \\
\hline & 125.000 & 125.000 & 150.000 & 175.000 & 200.000 & 225.000 \\
\hline & \multicolumn{6}{|c|}{ Fase V10 } \\
\hline 8.000 .000 & 0,47 & 0,57 & 0,66 & 0,76 & 0,85 & 0,94 \\
\hline 8.500 .000 & 0,44 & 0,53 & 0,62 & 0,71 & 0,80 & 0,89 \\
\hline 9.000 .000 & 0,42 & 0,50 & 0,59 & 0,67 & 0,76 & 0,84 \\
\hline 9.500 .000 & 0,40 & 0,48 & 0,56 & 0,64 & 0,72 & 0,80 \\
\hline 10.000 .000 & 0,38 & 0,45 & 0,53 & 0,60 & 0,68 & 0,76 \\
\hline 10.500 .000 & 0,36 & 0,43 & 0,50 & 0,58 & 0,65 & 0,72 \\
\hline 11.000 .000 & 0,34 & 0,41 & 0,48 & 0,55 & 0,62 & 0,69 \\
\hline 11.500 .000 & 0,33 & 0,39 & 0,46 & 0,53 & 0,59 & 0,66 \\
\hline \multirow[t]{2}{*}{12.000 .000} & 0,31 & 0,38 & 0,44 & 0,50 & 0,57 & 0,63 \\
\hline & \multicolumn{6}{|c|}{ Fase R1 } \\
\hline 8.000 .000 & 0,51 & 0,61 & 0,72 & 0,82 & 0,92 & 1,02 \\
\hline 8.500 .000 & 0,48 & 0,58 & 0,67 & 0,77 & 0,87 & 0,96 \\
\hline 9.000 .000 & 0,45 & 0,55 & 0,64 & 0,73 & 0,82 & 0,91 \\
\hline 9.500 .000 & 0,43 & 0,52 & 0,60 & 0,69 & 0,78 & 0,86 \\
\hline 10.000 .000 & 0,41 & 0,49 & 0,57 & 0,65 & 0,74 & 0,82 \\
\hline 10.500 .000 & 0,39 & 0,47 & 0,55 & 0,62 & 0,70 & 0,78 \\
\hline 11.000 .000 & 0,37 & 0,45 & 0,52 & 0,60 & 0,67 & 0,74 \\
\hline 11.500 .000 & 0,36 & 0,43 & 0,50 & 0,57 & 0,64 & 0,71 \\
\hline \multirow[t]{2}{*}{12.000 .000} & 0,34 & 0,41 & 0,48 & 0,55 & 0,61 & 0,68 \\
\hline & \multicolumn{6}{|c|}{ Fase R2 } \\
\hline 8.000 .000 & 0,62 & 0,74 & 0,87 & 0,99 & 1,12 & 1,24 \\
\hline 8.500 .000 & 0,58 & 0,70 & 0,82 & 0,93 & 1,05 & 1,17 \\
\hline 9.000 .000 & 0,55 & 0,66 & 0,77 & 0,88 & 0,99 & 1,10 \\
\hline 9.500 .000 & 0,52 & 0,63 & 0,73 & 0,84 & 0,94 & 1,04 \\
\hline 10.000 .000 & 0,50 & 0,60 & 0,69 & 0,79 & 0,89 & 0,99 \\
\hline 10.500 .000 & 0,47 & 0,57 & 0,66 & 0,76 & 0,85 & 0,95 \\
\hline 11.000 .000 & 0,45 & 0,54 & 0,63 & 0,72 & 0,81 & 0,90 \\
\hline 11.500 .000 & 0,43 & 0,52 & 0,60 & 0,69 & 0,78 & 0,86 \\
\hline 12.000 .000 & 0,41 & 0,50 & 0,58 & 0,66 & 0,74 & 0,83 \\
\hline
\end{tabular}


menghitung nilai AKE pada fase R1 dan R2 (Tabel 3).

\section{PEMBAHASAN}

Rata-rata hasil biji pada tanaman yang diinfestasi dengan larva penggerek batang jagung lebih rendah bila dibandingkan dengan kontrol. Semakin tinggi tingkat infestasi larva per tanaman semakin rendah rata-rata hasil biji untuk tiga fase tanaman karena terjadinya gangguan translokasi hara ke bagianbagian tanaman. Menurut James (2003); Cook et al. (2004) bahwa lubang gerekan pada batang akan menyebabkan penurunan gerakan hidrolik dalam batang dan gangguan sistem pembuluh sehingga mengurangi pergerakan air dari bawah ke bagian atas tanaman yang berfotosintesis yang dapat mengakibatkan berkurangnya jumlah dan bobot biji dalam tongkol.

Berdasarkan regresi linier, proporsi kehilangan hasil per larva per tanaman tertinggi pada fase tanaman V10 dibandingkan dengan fase R1 dan R2. Hal ini disebabkan oleh selisih hasil biji antara tanaman yang tidak diinfestasi larva (kontrol) dan infestasi larva tertinggi (enam larva per tanaman) yang lebih tinggi pada fase V10, disusul R1 dan R2, masing-masing 59,81; 58,76; dan 49,20 g/ tanaman. Data ini juga mengindikasikan bahwa fase tanaman yang lebih muda lebih rentan terhadap kerusakan oleh larva $O$. furnacalis. Menurut Bode et al. (2009) bahwa larva penggerek batang jagung yang memulai makan pada awal perkembangan tanaman jagung memiliki potensi untuk menyebabkan kehilangan hasil yang lebih besar dibandingkan dengan bila serangan dimulai pada fase tanaman yang lebih tua. Efek dari serangan larva penggerek batang jagung berkurang mulai dari fase reproduktif hingga masak fisiologis. Pada fase akhir pengisian biji, lubang gerekan pada batang hanya memberikan efek yang lebih rendah terhadap hasil.

Nilai AKE pada studi ini dapat digunakan sebagai dasar penentuan nilai ambang ekonomi (AE) untuk pegambilan keputusan pengendalian di lapangan. Secara umum AE ditentukan pada persentase tetap dari nilai AKE (fixed ecomomic threshold), misalnya penentuan nilai AE 50\% atau $70 \%$ dari nilai AKE (Pedigo 2009). Semakin cepat laju peningkatan populasi hama semakin besar jarak nilai $\mathrm{AE}$ di bawah nilai AKE dan apabila sifat dinamika populasi hama kurang diketahui maka nilai AE ditetapkan sedikit di bawah nilai AKE (Untung 2006).

Efikasi dari teknik pengendalian juga merupakan faktor yang dipertimbangkan untuk menentukan posisi nilai AE dari nilai AKE. Apabila teknik pengendalian yang akan digunakan dapat menurunkan populasi hama dalam waktu cepat maka nilai AE sedikit di bawah nilai AKE. Apabila teknik pengendalian yang digunakan membutuhkan waktu yang lebih lama untuk menurunkan populasi hama maka nilai $\mathrm{AE}$ agak jauh di bawah nilai AKE. Pemantauan populasi sesering mungkin sangat penting untuk penentuan pengambilan keputusan dalam pengendalian hama.

\section{KESIMPULAN}

Kehilangan hasil tanaman jagung meningkat dengan bertambahnya tingkat kepadatan populasi larva $O$. furnacalis per tanaman. Kehilangan hasil yang lebih tinggi terjadi fase tanaman yang lebih muda dibandingkan dengan fase tanaman yang lebih tua. Kehilangan hasil tertinggi berturutturut pada fase V10, R1, dan R2, dan nilai AKE meningkat dengan berkurangnya tingkat kehilangan hasil per fase tanaman. Penerapan hasil penelitian ini berlaku spesifik jika larva O. furnacalis menyerang batang, dan perlu pertimbangan lain jika serangan juga terjadi pada bunga jantan, bunga betina (rambut tongkol) dan tongkol.

\section{UCAPAN TERIMA KASIH}

Terima kasih disampaikan kepada Kepala Kebun Pendidikan, Penelitian, dan Pengembangan Pertanian (KP4) UGM, Yogyakarta yang telah memberi izin kepada penulis untuk penggunaan lahan penelitian di KP4; kepada Sriyanto Haryanto atas saran-sarannya pada teknis penelitian ini; Hendracipta dan Yosefus Da Lopes atas saransarannya pada tulisan ini. 


\section{DAFTAR PUSTAKA}

Abdullah T, Rauf A. 2011. Karakteristik populasi dan serangan penggerek jagung Asia, Ostrinia furnacalis (Lepidoptera: Pyralidae), dan hubungannya dengan kehilangan hasil. Jurnal Fitomedika 7:175-181.

Bode WM, Calvin DD. 1990. Yield-Loss relationships and economic injury levels for European corn borer (Lepidoptera: Pyralidae) populations infesting Pennsylvania field corn. Journal of Economic Entomology 83:1595-1608..

Bode WM, Calvin DD, Mason CE. 2009. How corn is damaged by the European corn borer. In Iowa State University, 2009. The European Corn Borer. Available at: http://www.ent.iastate.edu/pest/ cornborer/insect/damage [accessed 23 September 2011].

Capinera JL. 2008. Maize (Corn) pests and their management. In: John L. Capinera (Ed.), Encyclopedia of Entomology. $2^{\text {nd }}$ Edition. pp. 2266-2272. Netherlands: Springer Netherlands.

Cook KA, Susan TR, Michael EG, Kevin LS. 2004. European corn borer (Ostrinia nubilalis Hubner). University of Illinois at Urbana-Champaign. Available at: http://ipm.illinois.edu/fieldcrops/ insects/european_cornborer/factsheet.html [accessed 21 Januari 2012].

Douangboupha BT, Jamjanya N, Siri Y, Hanboonsong. 2006. Sweet corn insect pests and their control. Khon Kaen University Research Journal 6:25-37.

Granados G. 2000. Maize Insects: Tropical Maize, Improvement and Production. Rome: Food and Agriculture Organization of the United Nations.

Guo L, Li GQ. 2009. Olfactory perception of oviposition-deterring fatty acids and their methyl esters by the Asian corn borer, Ostrinia furnacalis. Journal of Insect Science 9:1-9.

James C. 2003. Global Review of Commercialized Transgenic Crops: 2002 Feature: Bt Maize. ISAAA Briefs No. 29. Ithaca: ISAAA.
Jordan TA. 2008. Pest Management Studies Of Early Season and Stalk-Boring Insects On Corn In Virginia. Master Thesis. Virginia: Virginia Polytechnic Institute and State University.

Litsinger JA, Dela Cruz CG, Canapi BL, Barrion AT. 2007. Maize planting time and arthropod abundance in Southern Mindanao, Philippines. I. population dynamics of insect pests. International Journal of Pest Management 53:147-159.

Nonci N. 2004. Biologi dan musuh alami penggerek batang Ostrinia furnacalis Guenee (Lepidoptera: Pyralidae) pada tanaman jagung. Jurnal Litbang Pertanian 23:8-14.

Ohno S, Sugihiko H, Sadahiro T, Yukio I. 2003. New record of Ostrinia ovalipennis (Lepidoptera: Crambidae) from Hokkaido, and Morphometric analyses for species identification and geographic variation. Applied Entomology and Zoology 38:529-535.

Pedigo LP. 2009. Economic threshold and economic injury levels (IPM World Textbook). University of Minnesota. Available at: http://ipmworld.umn. edu/chapters/pedigo.htm [accessed 19 July 2011].

SAS Institute. 2001. SAS user's guide: statistic. SAS Institute, Cary, NC.

Tiwari S, Youngman RR, Laub CA, Brewster CC, Jordan TA, Teutsch C. 2009. European corn borer (Lepidoptera: Crambidae) infestation level and plant growth stage on whole-plant corn yield grown for Silage in Virginia. Journal of Economic Entomology 102:2146-2153.

Untung K. 2006. Pengantar Pengelolaan Hama Terpadu Ed-2. Yogyakarta: Gadjah Mada University Press.

Walker PT. 1983. Crop losses: the need to quantify the effects of pests, diseases and weeds on agricultural production. Agriculture, Ecosystems and Environment 9:119-158.

Waterhouse DF. 1993. The Major Arthropod Pests and Weeds of Agriculture in Southeast Asia: Distribution, Importance and Origin. Canberra: ACIAR. 